\title{
In Vivo Antidiabetic Activities of Polyherbal Extracts against Streptozotocin- Nicotinamide Induced Type 2 Diabetic Mice Model
}

\author{
Pradnya Jagtap ${ }^{1}$, Yashashri Nimbalkar ${ }^{1}$, Vidya Patil ${ }^{2 *}$ and Ravindra Y. Patil ${ }^{3}$ \\ ${ }^{1}$ PDEA'S Seth Govind Raghunath Sable College of Pharmacy, Saswad, Maharashtra, India \\ ${ }^{2}$ Department of Botany, Waghire College, Saswad Pune, Maharashtra, India \\ ${ }^{3}$ PDEA's Shankarro Ursal College of Pharmaceutical Sciences and Research Centre, Pune, \\ Maharashtra, India \\ *Corresponding author, email: patilvidya14@gmail.com \\ Co-authors'e-mails:pnj1511@gmail.com, yashashri159@gmail.com, rypatil1971@yahoo.co.in
}

Received 9 May 2021, Revised 11 Jul 2021, Accepted 20 Jul 2021, Published Aug 2021

DOI: https://dx.doi.org/10.4314/tjs.v47i3.1

\begin{abstract}
Diabetes mellitus is a chronic metabolic disorder and rapidly increasing cases of diabetes throughout the world are major concerns in both developed and developing countries. Currently available oral antidiabetic medicines have limitations in efficacy and safety, which in conjunction with the emergence of diabetes mellitus as a global epidemic have aided the popularity of alternative therapies to manage the disease safely and more efficiently. Herbal medicines are accepted as alternative therapies for blood sugar control. Gymnema sylvestre, Boerhavia diffusa, Tinospora cordifolia, and Argyreia nervosa are some potent herbs used for the management of diabetes. Mixing of these plants in different ratios may produce synergistic antidiabetic actions which may have greater antidiabetic activity. Hence, the present study aimed to determine the antidiabetic activities of polyherbal extracts in streptozotocin-nicotinamide induced type 2 diabetic mice. The administration of polyherbal extract orally at doses of 100,200 and $400 \mathrm{mg} / \mathrm{kg}$ significantly decreased the blood glucose levels compared to the control diabetic mice. The polyherbal extract significantly lowered the elevated total cholesterol, triglycerides and lowdensity lipoprotein levels, while increased the high-density lipoprotein indicating antihyperlipidemic activity. The present study reveals that polyherbal extract at a dose of 400 $\mathrm{mg} / \mathrm{kg}$ body weight resulted in a significant decline $(\mathrm{p}<0.001)$ in blood glucose level.
\end{abstract}

Keywords: Polyherbal extracts, diabetes mellitus, Oral glucose tolerance test, StreptozotocinNicotinamide.

\section{Introduction}

Diabetes mellitus (DM) is a chronic metabolic disorder characterized by hyperglycaemia caused by reduced insulin secretion, decreased glucose utilization and increased glucose production (Undale et al. 2014, Mouri and Badireddy 2019). Glucose homeostasis is a balance between hepatic glucose production and peripheral glucose uptake and utilization. Insulin is the most important regulator of glucose homeostasis (Simon and Wittmann 2019, Yari et al. 2020). Diabetes mellitus is classified into general categories like type 1, type 2, gestational diabetes, among other specific types of diabetes. Type 1 diabetes is caused by B-cell destruction, usually leading to absolute insulin deficiency. Type 2 diabetes is a result of progressive insulin secretory defects in conjunction with insulin resistance. Gestational 
diabetes mellitus (GDM) is a diabetes type usually diagnosed in the second or third trimester of pregnancy and is not clearly evident in diabetes. Other uncommon diabetes types include monogenic diabetes syndromes such as neonatal diabetes, maturity-onset diabetes of the young (MODY), diabetes resulting from diseases of the exocrine pancreas (such as cystic fibrosis), and drug or chemical induced diabetes such as in the treatment of HIV/AIDS or after organ transplantation (American Diabetes Association,

https://www.diabetes.org/diabetes). Diabetes mellitus is a serious metabolic disease that has significant impacts on the health, quality of life and life expectancy of patients (Sancheti and Seo 2009). According to the reports of the World Health Organization, the rapid increase of diabetes in India is indicative of a potential epidemic with over 62 million individuals currently diagnosed and future projections indicating a rapid increase in numbers (Wild et al. 2004). In 2000, India had the highest number of people with diabetes mellitus (31.7 million) followed by China (20.8 million) and United States (17.7 million) in second and third places. The global prevalence of diabetes is predicted to double from 171 million in 2000 to 366 million in 2030 with India seeing the highest increase with numbers nearing 80 million (Wild et al. 2004).

There are various synthetic drugs used for the treatment of hyperglycaemia. The synthetic drugs have various side effects such as causing hyperglycaemia at higher doses, dermatological reactions, liver problems, nausea, vomiting, generalized hypersensitivity reactions, lactic acidosis and diarrhoea. These anti-diabetic drugs also cause weight gain which may further contribute to the progression of type 2 diabetes. The secondary complications arising from the use of synthetic drugs lead to limitations in their uses and potentially create issues in the management of diabetes (Chaudhuri and Sharma 2016). So, there is a need to develop safe and economic alternative treatments for diabetes mellitus. Therefore, there is considerable interest in the field of medicinal plants due to their natural origins and fewer side effects (El-Shafey et al. 2013). The World Health Organization also recommended and encouraged the practice of herbal medicines especially in countries where access to the conventional treatments of diabetes is inadequate.

The pharmacological activity of a single plant is less when compared to polyherbal formulations that contain combinations of various plants. Polyherbal formulations produce synergistic actions which are more potent and also diminish the concentrations of individual herbs, thereby reducing adverse effects (Shah et al. 2019).

In the present study, polyherbal formulations which consisted of extracts of Gymnema sylvestre, Boerhavia diffusa, Tinospora cordifolia, and Argyreia nervosa were used to determine hypoglycaemic activities. The herbs used in the formulations are reported in traditional medicines to treat diabetes mellitus and their active phytoconstituents like gymnemic acids, gymnemosides a, b, c, d, e, and $\mathrm{f}$ and gymnemosaponins (Kanetkar et al. 2007, Mishra et al. 2014), punarnavine-1, $\beta$-sitosterol (Sharma et al. 2019), tinosporin (Galani et al. 2010), quercetin and kaempferol (Gosh 1984) etc. Their details are given in Table 1 . Therefore, in the present investigation, the polyherbal formulations were evaluated for hypoglycaemic activity in streptozotocinnicotinamide (STZ-NIC) induced diabetes in mice. 
Table 1: Phytoconstituents of polyherbs used for polyherbal extract preparation

\begin{tabular}{|c|c|c|}
\hline Sr.No. & Plant name & Phytochemical constituents \\
\hline 1 & $\begin{array}{l}\text { Gymnema sylvestre } \mathrm{R} \text {. } \\
\mathrm{Br} \text {. }\end{array}$ & $\begin{array}{l}\text { Gymnemic acid I-IV, Gymnemasaponins, } \\
\text { Gymnemosides a, b, c, d, e, and f, Kaempferol 3-O- } \\
\beta \text {-D-glucopyranosyl-(1-4)- } \alpha \text {-L-rhamnopyranosyl-(1- } \\
\text { 6)- } \beta \text {-D-galactopyranoside, Stigmasterol, Conduritol } \\
\text { A and Quercitol (Kanetkar et al. 2007) }\end{array}$ \\
\hline 2 & Boerhavia diffusa $\mathrm{L}$. & $\begin{array}{l}\text { Punarnavine-1 \& } 2 \text {, Boeravinone A-I, 9-O-Methyl- } \\
\text { 10-hydroxy coccineone E, 10-dimethyl boeravinone } \\
\text { C, Coccineone E, } \beta \text {-Sitosterol } \\
\beta \text {-Sitosterol-D-glucoside, } \beta \text {-Sitosteryl oleate, } \\
\text { Sitosteryl palmitate, Liriodendrin, Stringarsionol } \\
\text { and Mono-D-glucoside and } \beta \text {-D-glucoside (Mishra } \\
\text { et al. 2014) }\end{array}$ \\
\hline 3 & $\begin{array}{l}\text { Tinospora cordifolia } \\
\text { (Thunb.) Miers }\end{array}$ & $\begin{array}{l}\text { Tinosporide, Furanolactone } \\
\text { Furanolactone clerodane diterpene, furanoid } \\
\text { diterpene, Tinosporaside, Giloinsterol, B-Sitosterol, } \\
\text { 20a- Hydroxy ecdysone, Giloin, Tinosporan acetate, } \\
\text { Tinosporal acetate, Tinosporidine, Heptacosanol, } \\
\text { Octacosanol, sinapic acid, Tinosponone, and } \\
\text { 2- phytoecdysones (Sharma et al. 2019) }\end{array}$ \\
\hline 4 & $\begin{array}{l}\text { Argyreia nervosa } \\
\text { (Burm.f.) Bojer }\end{array}$ & $\begin{array}{l}\text { 1-Triacontanol, Epifriedelinol Acetate, } \\
\text { Epifriedelinol and } \beta \text {-Sitosterol, N-Triacontanol, B- } \\
\text { Sitosterol, P-Hydroxycinnamoyl Octadecanolate, } \\
\text { Caffeic acid, p-Hydroxycinnamate, Hexadecanyl p- } \\
\text { hydroxycinnamate, L-Ester coumarin and } \\
\text { Tetradecanyl palmitate (Galani et al. 2010, Gosh } \\
\text { 1984) }\end{array}$ \\
\hline
\end{tabular}

\section{Materials and Methods \\ Plant materials}

The leaves of Gymnema sylvestre (Asclepiadaceae), whole plant of Boerhavia diffusa (Nyctaginaceae), stem and leaves of Tinospora cordifolia (Menispermaceae) and whole plant of Argyreia nervosa (Convolvulaceae) were collected from local regions around Purandar town in Maharashtra and Pune University campus. Freshly collected plants were pressed in a herbarium press and dried plant specimens mounted on herbarium sheet. All the information provided and herbaria were submitted to the Botanical Survey of India (BSI) Herbarium in Pune for authentication; the corresponding voucher numbers are VP-11, VP-10, VP-9 and VP-7. The plant parts were washed with distilled water to remove dirt and soil, and then shade dried.

\section{Preparation of extracts}

The selected parts of plants were washed and dried under shade for 20 days. The dried plants were pulverized using a mechanical grinder and powdered for further studies and extracted with $80 \%$ absolute ethanol using Soxhlet apparatus for 6 hours. The extracts were evaporated to dryness (resinous material) under reduced pressure at $60{ }^{\circ} \mathrm{C}$ and stored at 4 ${ }^{\circ} \mathrm{C}$ until use. The polyherbal formulation was developed by combining the dried extracts of the plant extracts (Mandlik 2008, Maurya et al. 2011). 
Jagtap et al. - In Vivo Antidiabetic Activities of Polyherbal Extracts against Streptozotocin ...

\section{Preparation of polyherbal mixture}

Polyherbal mixture was prepared by mixing individually extracted powders of plants Gymnema sylvestre, Boerhavia diffusa, Tinospora cordifolia, and Argyreia nervosa. The concentration of each plant in the plant polyherbal extract mixture was decided according to their potent antidiabetic activity at that concentration. Gymnema sylvestre shows potent antidiabetic activity at a dose of 400 $\mathrm{mg} / \mathrm{kg}$ (Aralelimath and Bhise 2012), and the average weight of the experimental animal is $27 \mathrm{~g}$, so, $10.8 \mathrm{mg}$ of Gymnema sylvestre was used in the polyherbal mixture. Boerhavia diffusa shows potent antidiabetic activity at a dose of $200 \mathrm{mg} / \mathrm{kg}$ (Malhotra et al. 2014), so $5.4 \mathrm{mg}$ of Gymnema sylvestre was used in the polyherbal mixture. Tinospora cordifolia shows potent antidiabetic activity at a dose of $400 \mathrm{mg} / \mathrm{kg}$ (Puranik et al. 2010), so $10.8 \mathrm{mg}$ of Gymnema sylvestre was used in the polyherbal mixture. Argyreia nervosa shows potent antidiabetic activity at a dose of $500 \mathrm{mg} / \mathrm{kg}$ (Kumar and Alagawadi 2010), so $13.5 \mathrm{mg}$ of Gymnema sylvestre was used in the polyherbal mixture. All these powders were mixed well to make polyherbal mixtures, and this prepared polyherbal mixture was administered to an animal with water at different concentrations $(100,200$ and $400 \mathrm{mg} / \mathrm{kg})$.

\section{Chemicals and reagents}

Streptozotocin, nicotinamide and glucose were obtained from Sigma. Other chemicals and reagents used in the study were of analytical grade.

Determination of in vivo antidiabetic activity Animals: Swiss albino mice bred in the animal house facility of PDEA's SGRS College of Pharmacy were used. The animals were maintained under controlled temperature, humidity and light cycle as prescribed by the Committee for the Purpose of Control and Supervision of Experiments on Animals (CPCSEA). Standard animal pellet diet and water were provided ad libitum. The experimental protocol was approved by the
Institutional Animal Ethics Committee (IAEC) (SGRS/ IAEC/ 07/2018-19) and experiments were conducted according to the guidelines of the CPCSEA.

\section{Experimental design \\ Acute oral toxicity tests of the polyherbal extract}

An acute oral toxicity study was carried out according to OECD guidelines 423. In this method pre-specific fixed doses of the test substances were used, i.e., $5 \mathrm{mg} / \mathrm{kg}, 50 \mathrm{mg} / \mathrm{kg}$, $300 \mathrm{mg} / \mathrm{kg}, 2000 \mathrm{mg} / \mathrm{kg}, 5000 \mathrm{mg} / \mathrm{kg}$ and the mortality rates due to these doses were observed. Generally, the female was used for this study and each dose Group consisted of 3 animals.

\section{Effect of polyherbal formulation on oral glucose tolerance test (OGTT)}

The oral glucose tolerance test was performed in overnight fasted (12-14 hrs) mice. The mice were divided into six Groups $(n=6)$.

Group I: served as normal control mice, administered drinking water daily.

Group II: had glucose control mice.

Group III: mice were administered standard drug metformin $(250 \mathrm{mg} / \mathrm{kg})$.

(The dose of metformin administered to mice in this study was calculated according to a clinically relevant human dose based on body surface area. Metformin $250 \mathrm{mg} / \mathrm{kg}$ )

Group IV: mice were administered polyherbal extract of $100 \mathrm{mg} / \mathrm{kg}$.

Group V: mice were administered polyherbal extract of $200 \mathrm{mg} / \mathrm{kg}$.

Group VI: mice were administered polyherbal extract of $400 \mathrm{mg} / \mathrm{kg}$.

Glucose $(2 \mathrm{~g} / \mathrm{kg})$ was fed to mice of groups II to VI, 30 minutes before the administration of the extracts and standard drug. Blood was withdrawn from the retro-orbital sinus after 0 , 30, 60, 90 and 120 minutes of extract and standard drug administration, and the plasma obtained after centrifugation at $3000 \mathrm{rpm}$ was estimated for fasting plasma glucose levels glucometer (Turner 1965, Gosh 1984, Zhang et al. 2002, Chaudhuri and Sharma 2016). 


\section{Induction of diabetes mellitus (non-insulin dependent diabetes mellitus)}

In overnight fasted mice, streptozotocin (STZ) was injected $(50 \mathrm{mg} / \mathrm{kg}$ in $0.1 \mathrm{~mL}$ citrate buffer pH 4.5 i.p.) 15 min after nicotinamide (NIC) injection $(120 \mathrm{mg} / \mathrm{kg}$ in $0.1 \mathrm{~mL}$ normal saline) in all the groups except for Group I which was the non-diabetic control i.e., Normal control. Animals were fed with glucose solution (5\%) for $12 \mathrm{hrs}$ to avoid hypoglycaemia. Hyperglycaemia was confirmed after 3 days. Mice having serum glucose $>250 \mathrm{mg} / \mathrm{dl}$ were selected for the study (Birgani et al. 2018).

\section{Evaluation of antidiabetic activity}

The animals were divided into six Groups (IVI) of six mice each as mentioned previously and Groups III to VI were treated with test drugs. The fasting glucose levels were determined on days $0,7,14,21$ and 28 of extract administration. During the experimental period, the mice were weighed daily and the mean changes in body weights were calculated.

\section{Estimation of biochemical parameters}

On day 28, the animals were sacrificed by cervical dislocation to determine the biochemical parameters. triglycerides (TGL), low density lipoprotein (LDL), cholesterol and high-density lipoprotein (HDL) were determined (Rakieten et al. 1963, Nagja et al. 2017, Sheikh et al. 2015).

\section{Statistical analysis}

Results were analysed statistically using the One-Way ANOVA method followed by Bonferroni Test (multiple comparison test). The minimum level of significance was set at $\mathrm{p}$ $<0.05$. The data are presented as the mean \pm SEM.

\section{Results \\ Acute oral toxicity according to OECD guidelines 423}

In acute oral toxicity study, oral administration of the polyherbal extracts at the doses of $5 \mathrm{mg} / \mathrm{kg}, 50 \mathrm{mg} / \mathrm{kg}, 300 \mathrm{mg} / \mathrm{kg}, 2000$ $\mathrm{mg} / \mathrm{kg}, 5000 \mathrm{mg} / \mathrm{kg}$ body weight did not induce any changes in behaviour and no mortality was observed during the study. There was no significant difference in the body weight and food consumption when compared to the normal control group. On the $7^{\text {th }}$ day, macroscopic pathology observations revealed no visible lesions in any animals after sacrifice. The observed data suggested that the oral $\mathrm{LD}_{50}$ value of polyherbal extract is greater than 2000 $\mathrm{mg} / \mathrm{kg}$ body weight. Therefore, polyherbal extract can be safely used as a dose up to 2000 $\mathrm{mg} / \mathrm{kg}$ body weight for therapeutic use.

Selected doses: $100 \mathrm{mg} / \mathrm{kg}, 200 \mathrm{mg} / \mathrm{kg}, 400$ $\mathrm{mg} / \mathrm{kg}$.

\section{Effects of polyherbal extracts on body weight}

The effects of the polyherbal extracts on the bodyweight of animals were checked, the results of which are presented in Table 2. The body weight measured in grams in Group II (Disease control) was observed to be $20.17 \pm$ $0.5426 \mathrm{~g}$ on the $28^{\text {th }}$ day. Significantly ( $\mathrm{p}<$ 0.001 ) decreased level of bodyweight in Group II (Disease control) was observed as compared to Group I (Normal control). In Groups III, IV, $\mathrm{V}$ and VI significant $(\mathrm{p}<0.001)$ increase in body weight was observed as compared to Group II (Disease control). In Group VI, significant $(p<0.01)$ increase in body weight as compared to Group III (Standard control). All data were subjected to the One-Way ANOVA method followed by Bonferroni's multiple comparisons test and given in Figure 1. 
Jagtap et al. - In Vivo Antidiabetic Activities of Polyherbal Extracts against Streptozotocin ...

Table 2: Effects of polyherbal extracts on body weight of STZ-NIC induced diabetic mice

\begin{tabular}{|c|c|c|c|c|c|c|}
\hline \multirow{2}{*}{ S.No. } & \multirow{2}{*}{$\begin{array}{c}\text { Treatment } \\
\text { Group }\end{array}$} & \multicolumn{5}{|c|}{ Body weight (g) } \\
\hline & & 0 Day & $7^{\text {th }}$ Day & $14^{\text {th }}$ Day & $21^{\text {th }}$ Day & $28^{\text {th }}$ Day \\
\hline I & $\begin{array}{l}\text { Normal } \\
\text { Control }\end{array}$ & $\begin{array}{c}27 \pm \\
0.5164\end{array}$ & $\begin{array}{l}26.5 \pm \\
0.4282\end{array}$ & $\begin{array}{l}26.5 \pm \\
0.3416\end{array}$ & $\begin{array}{c}26.83 \pm \\
0.4779\end{array}$ & $\begin{array}{l}27.17 \pm \\
0.4014\end{array}$ \\
\hline II & $\begin{array}{l}\text { Disease } \\
\text { (Diabetic) } \\
\text { control }\end{array}$ & $\begin{array}{c}28.33 \pm \\
0.3073^{\mathrm{NS}}\end{array}$ & $\begin{array}{c}26.33 \pm \\
0.3333^{\mathrm{NS}}\end{array}$ & $\begin{array}{c}24.5 \pm \\
0.4282^{\mathrm{NS}}\end{array}$ & $\begin{array}{l}23.17 \pm \\
0.7032^{*}\end{array}$ & $\begin{array}{c}20.17 \pm \\
0.5426^{* * *}\end{array}$ \\
\hline III & $\begin{array}{l}\text { Standard } \\
\text { Treated }\end{array}$ & $\begin{array}{c}27.33 \pm \\
0.8433^{\mathrm{NS}}\end{array}$ & $\begin{array}{l}26.37 \pm \\
1.022^{\mathrm{NS}}\end{array}$ & $\begin{array}{c}27.5 \\
\pm 0.8062^{\mathrm{NS}}\end{array}$ & $\begin{array}{c}26.17 \pm \pm \\
0.9804^{\mathrm{NS}}\end{array}$ & $\begin{array}{c}25.67 \pm \pm \\
0.8028^{* * * *}\end{array}$ \\
\hline IV & $\begin{array}{l}\text { Polyherbal } \\
\text { extract } \\
\text { treated I } \\
100 \mathrm{mg} / \mathrm{kg}\end{array}$ & $\begin{array}{c}30.5 \pm \\
0.9916^{\mathrm{NS}, \mathrm{NS}}\end{array}$ & $\begin{array}{c}28.67 \pm \pm \\
0.9545^{\mathrm{NS}, \mathrm{NS}}\end{array}$ & $\begin{array}{c}27.5 \pm \\
0.8062^{\mathrm{NS}, \mathrm{NS}}\end{array}$ & $\begin{array}{c}26.50 \pm \\
0.5627^{*}, \mathrm{NS}\end{array}$ & $\begin{array}{c}25 \pm \pm \\
0.5164^{* *, N S}\end{array}$ \\
\hline V & $\begin{array}{l}\text { Polyherbal } \\
\text { extract } \\
\text { treated II } \\
200 \mathrm{mg} / \mathrm{kg}\end{array}$ & $\begin{array}{c}30 \pm \\
0.4472^{\text {NS,NS }}\end{array}$ & $\begin{array}{c}29.17 \pm \\
0.4773^{\mathrm{NS}, N S}\end{array}$ & $\begin{array}{c}28.5 \pm \\
0.6708^{* *, N S}\end{array}$ & $\begin{array}{c}27.67 \pm \\
0.5578^{* *, N S}\end{array}$ & $\begin{array}{c}27.17 \pm \\
0.8333^{* * *, N S}\end{array}$ \\
\hline VI & $\begin{array}{l}\text { Polyherbal } \\
\text { extract } \\
\text { treated III } \\
400 \mathrm{mg} / \mathrm{kg}\end{array}$ & $\begin{array}{c}28.33 \\
\pm 1.145^{\mathrm{NS}, \mathrm{NS}}\end{array}$ & $\begin{array}{c}28 \\
\pm 1.211^{\mathrm{NS}, \mathrm{NS}}\end{array}$ & $\begin{array}{c}27.33 \\
\pm 1.054^{\mathrm{NS}, \mathrm{NS}}\end{array}$ & $\begin{array}{c}27.50 \\
\pm 1.057^{* *, N S}\end{array}$ & $\begin{array}{c}29.17 \\
\pm 0.8724^{* * *, \# \#}\end{array}$ \\
\hline
\end{tabular}

Notes: All values are expressed as mean \pm SEM. $\mathrm{N}=6$. All data are subjected to One Way ANOVA followed by Bonferroni's multiple comparisons test; here Group II is compared with Group I and Groups III, IV, V and VI are compared with Group II. *p $<0.05$, **p $<0.01, * * * p<$ 0.001, NS: Not Significant. Multiple Comparison: Groups IV, V, VI are compared with Group III. \# $\mathrm{p}<0.05$, \#\# $\mathrm{p}<0.01$, \#\#\# $\mathrm{p}<0.001$, NS: Not Significant.

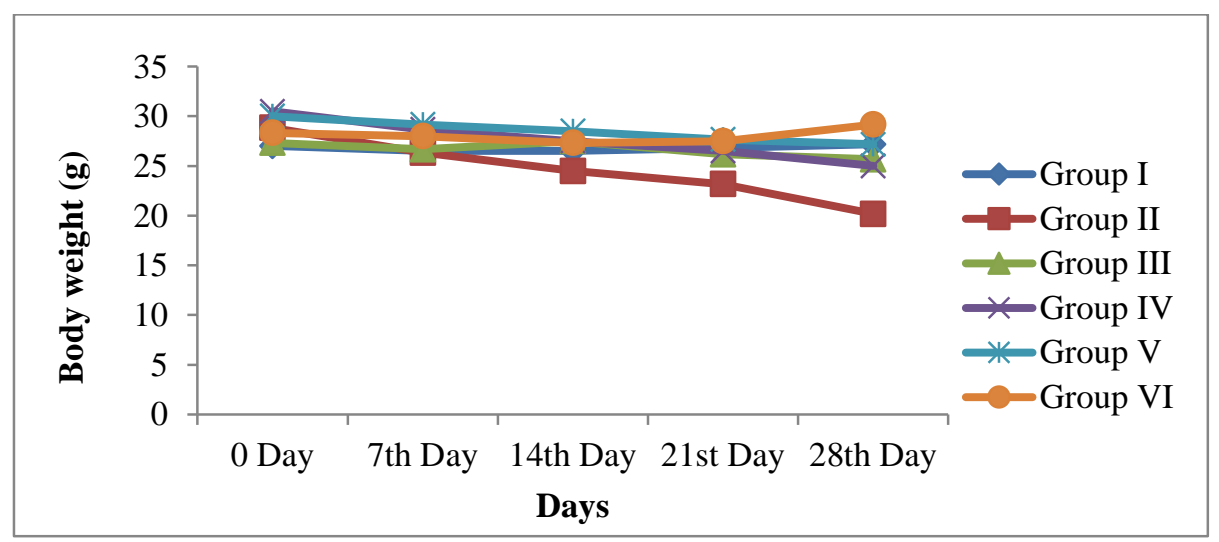

Figure 1: Effects of polyherbal extracts on body weights in STZ-NIC induced diabetic mice; values are expressed as mean \pm SEM, $n=6$. Where, Group I: Normal control, Group II: Disease control, Group III: Standard control, Group IV: polyherbal extract treated $100 \mathrm{mg} / \mathrm{kg}$, Group V: polyherbal extract treated $200 \mathrm{mg} / \mathrm{kg}$, Group VI: polyherbal extract treated $400 \mathrm{mg} / \mathrm{kg}$. 


\section{Effects of the polyherbal extracts on oral glucose tolerance}

The effects of the polyherbal extracts on the blood glucose level measured with Glucopoint One-touch glucometer in Group II (Disease control) were observed to be $320.2 \pm$ $9.513 \mathrm{mg} / \mathrm{dl}$ at $120 \mathrm{~min}$. All the readings are given in Table 3 and significant $(\mathrm{p}<0.001)$ increase in blood glucose level in Group II (Disease control) was observed as compared to Group I (Normal Control). In Group VI polyherbal extract-treated III $400 \mathrm{mg} / \mathrm{kg}$, a significant $(\mathrm{p}<0.001)$ decrease in blood glucose level at 60, 90 and $120 \mathrm{~min}$ was observed as compared to Group II (Disease control). In a similar comparison against Group III (Standard control) treated with metformin (250 mg/kg, p.o.), Group VI polyherbal extract-treated III $400 \mathrm{mg} / \mathrm{kg}$ showed a significant $(p<0.001)$ decrease in blood glucose level at $90 \mathrm{~min}$ and $120 \mathrm{~min}$. The results suggest the potential effects of polyherbal extract-treated at dose of $400 \mathrm{mg} / \mathrm{kg}$ at 90 and 120 mins of treatment (Figure 2).

Table 3: Effects of polyherbal extracts on oral glucose tolerance test in STZ-NIC induced diabetic mice

\begin{tabular}{|c|c|c|c|c|c|c|}
\hline \multirow{2}{*}{ S.No } & \multirow{2}{*}{$\begin{array}{l}\text { Treatment } \\
\text { Group }\end{array}$} & \multicolumn{5}{|c|}{ Plasma glucose concentrations (mg/dl) } \\
\hline & & 0 min & 30 min & $60 \mathrm{~min}$ & $90 \mathrm{~min}$ & $120 \mathrm{~min}$ \\
\hline $\mathbf{I}$ & $\begin{array}{l}\text { Normal } \\
\text { Control }\end{array}$ & $\begin{array}{l}93.67 \\
1.145\end{array}$ & $\begin{array}{l}129.2 \\
1.537\end{array}$ & $\begin{array}{l}146.7 \\
1.453\end{array}$ & $\begin{array}{l}129.3 \\
2.108\end{array}$ & $\begin{array}{l}94.33 \pm \\
0.8819\end{array}$ \\
\hline II & $\begin{array}{l}\text { Disease } \\
\text { (Diabetic) } \\
\text { control } \\
\end{array}$ & $\begin{array}{l}326.0 \\
8.839^{* * *}\end{array} \quad \pm$ & $\underset{* * *}{350.7} \pm 10.7$ & $\begin{array}{l}371.2 \\
9.41^{* * *}\end{array}$ & $\begin{array}{l}349.2 \\
10.03^{* * *}\end{array} \pm$ & $\begin{array}{l}320.2 \pm \\
9.513^{\text {*** }}\end{array}$ \\
\hline III & $\begin{array}{l}\text { Standard } \\
\text { Control }\end{array}$ & $\begin{array}{l}313.3 \quad \pm \\
9.510^{\mathrm{NS}}\end{array}$ & $\begin{array}{l}329.0 \pm 9.29 \\
\text { NS }\end{array}$ & $\begin{array}{l}309.3 \\
9.59^{* * *}\end{array}$ & $\begin{array}{l}292.2 \\
7.026^{* * * *}\end{array}$ & $\begin{array}{l}263.8 \pm \\
9.888^{\text {**** }}\end{array}$ \\
\hline IV & $\begin{array}{l}\text { Polyherbal } \\
\text { extract } \\
\text { treated I } 100 \\
\mathrm{mg} / \mathrm{kg}\end{array}$ & $\begin{array}{l}324.3 \\
8.804^{\mathrm{NS}}\end{array}$ & $\begin{array}{l}342 \\
8.021^{\mathrm{NS}}\end{array}$ & $\begin{array}{l}354.0 \pm \\
6.127^{\mathrm{NS}, \# \#}\end{array}$ & $\begin{array}{l}343.5 \pm \\
6.339^{\mathrm{NS}, \# \# \#}\end{array}$ & $\begin{array}{l}329.8 \pm \\
6.041^{\mathrm{NS}, \#} \\
\# \#\end{array}$ \\
\hline $\mathbf{V}$ & $\begin{array}{l}\text { Polyherbal } \\
\text { extract } \\
\text { treated II } 200 \\
\mathrm{mg} / \mathrm{kg}\end{array}$ & $\begin{array}{l}326.2 \pm \\
9.228 \text { NS,NS }\end{array}$ & $\begin{array}{l}334.3 \\
8.920^{\mathrm{NS}, N S}\end{array}$ & $\begin{array}{l}330.5 \\
9.66^{* *, N S}\end{array} \pm$ & $\begin{array}{l}324.8 \pm \\
9.428^{\mathrm{NS}, \#}\end{array}$ & $\begin{array}{l}317.2 \pm \\
9.407^{\mathrm{NS}, \#} \\
\# \#\end{array}$ \\
\hline VI & $\begin{array}{l}\text { Polyherbal } \\
\text { extract } \\
\text { treated III } \\
400 \mathrm{mg} / \mathrm{kg}\end{array}$ & $\begin{array}{l}310.0 \pm \\
8.14^{\mathrm{NS}, \mathrm{NS}}\end{array}$ & $\begin{array}{l}328.5 \\
11.95^{N S, N S}\end{array}$ & $\begin{array}{l}295.8 \pm \\
7.300^{* * *, N S}\end{array}$ & $\begin{array}{l}249.2 \pm \\
3.745^{* * *, \# \#} \\
\#\end{array}$ & $\begin{array}{l}199.7 \pm \\
0.9888 \\
* * *, \# \# \#\end{array}$ \\
\hline
\end{tabular}

Notes: All values are expressed as mean \pm SEM, $n=6$. All data are subjected to One Way ANOVA followed by Bonferroni's multiple comparisons test; here Group II is compared with Group I and Groups III, IV, V and VI are compared with Group II. *p $<0.05, * * p<0.01, * * * p<$ 0.001 , NS: Not Significant. Multiple Comparison: Groups IV, V and VI are compared with Group III. \# p $<0.05, \# \#$ p $<0.01, \# \#$ p $<0.001$, NS: Not Significant. 
Jagtap et al. - In Vivo Antidiabetic Activities of Polyherbal Extracts against Streptozotocin ...

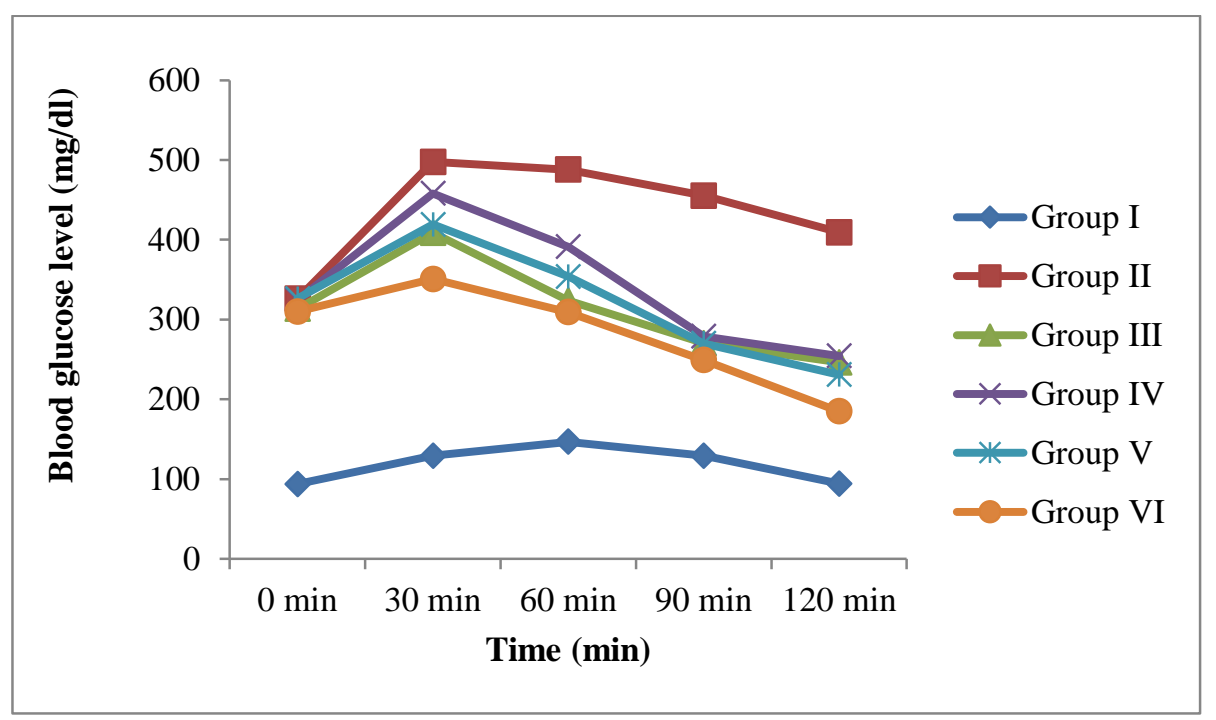

Figure 2: Effects of polyherbal extracts on oral glucose tolerance test in STZ-NIC induced diabetic mice; values are expressed as mean $\pm \mathrm{SEM}, \mathrm{n}=6$. Where, Group I: Normal control, Group II: Disease control, Group III: Standard control, Group IV: polyherbal extract treated 100 $\mathrm{mg} / \mathrm{kg}$, Group V: polyherbal extract treated $200 \mathrm{mg} / \mathrm{kg}$, Group VI: polyherbal extract treated 400 $\mathrm{mg} / \mathrm{kg}$.

Effects of the polyherbal extracts on noninsulin-dependent diabetes mellitus

In the sub-acute study conducted in the STZ-NIC induced diabetic mice, the blood glucose level in Group II (Disease control) was found to be $316.7 \pm 6.800 \mathrm{mg} / \mathrm{dl}$ (Table 4). Significant $(p<0.001)$ increase in blood glucose level in Group II (Disease control) was observed as compared to Group I (Normal control). At the end of 28 days of treatment schedule, significant $(\mathrm{p}<0.001)$ decrease in the blood glucose level was observed in
Groups III, IV, V and VI compared to Group II (Disease control). In Group VI, significant ( $\mathrm{p}<$ 0.01 ) decrease in blood glucose level at 28 days was observed as compared to Group III (Standard control) treated with metformin (250 $\mathrm{mg} / \mathrm{kg}$, p.o.). While in Groups IV and V, no significant decrease in blood glucose level at 28 days was observed as compared to Group III. The results suggest the potential effects of polyherbal extract-treated at dose of $400 \mathrm{mg} / \mathrm{kg}$ at 14, 21 and 28 days of treatment (Figure 3). 
Table 4: Effects of polyherbal extracts on blood glucose level in STZ-NIC induced diabetic mice

\begin{tabular}{|c|c|c|c|c|c|c|c|}
\hline \multirow{2}{*}{$\begin{array}{l}\text { Sr. } \\
\text { No }\end{array}$} & \multirow{2}{*}{$\begin{array}{l}\text { Treatment } \\
\text { Group }\end{array}$} & \multicolumn{6}{|c|}{ Fasting plasma glucose concentration (mg/dl) } \\
\hline & & Day 0 & $7^{\text {th }}$ Day & $14^{\text {th }}$ Day & $21^{\text {st }}$ Day & & $28^{\text {th }}$ Day \\
\hline \multirow{2}{*}{ I } & Normal & 96 & 96.17 & 96.33 & 97.50 & \pm & 97.67 \\
\hline & Control & 0.6831 & 0.4014 & 0.3333 & 0.4232 & & 0.4216 \\
\hline \multirow{2}{*}{ II } & Disease & 309.5 & 311.5 & 316.7 & 314.2 & \pm & 316.7 \\
\hline & $\begin{array}{l}\text { (Diabeti } \\
\text { control }\end{array}$ & $7.018^{* * *}$ & $6.662^{*}$ & $7.592^{*}$ & $7.609^{* * *}$ & & $6.800^{* * *}$ \\
\hline \multirow{2}{*}{ III } & Standard & $325 \pm$ & 316.7 & $221.3 \pm$ & 165.6 & \pm & $101.3 \pm$ \\
\hline & Control & $7.043^{\mathrm{NS}}$ & $7.592^{\mathrm{NS}}$ & $10.93^{* * *}$ & $8.036^{* * *}$ & & $1.874^{* * *}$ \\
\hline \multirow[b]{2}{*}{ IV } & Polyherbal & & 289.5 & & & \pm & \\
\hline & extract treated & $7.043^{\mathrm{NS}, \mathrm{NS}}$ & $6.893^{\mathrm{NS}, \#}$ & $6.061^{* * *, N S}$ & $3.964^{* * *, \# \#}$ & & $3.745^{* * *, N S}$ \\
\hline \multirow[b]{2}{*}{ V } & Polyherbal & 329 & 287.7 & 232.5 & 164.2 & \pm & 112.3 \\
\hline & $\begin{array}{l}\text { extract treated } \\
\text { II } 200 \mathrm{mg} / \mathrm{kg}\end{array}$ & $7.033^{\mathrm{NS}}$ & $4.197^{\mathrm{NS}, \#}$ & $5.464^{*}$ & $4.534^{*}$ & & $2.060^{*}$ \\
\hline \multirow{2}{*}{ VI } & Polyherbal & 323.8 & 283.3 & 218.7 & 156.0 & \pm & 100.8 \\
\hline & $\begin{array}{l}\text { extract treat } \\
\text { III } 400 \mathrm{mg} / \mathrm{k}\end{array}$ & $5.231^{\mathrm{NS}}$ & 5,783* \#\# & $9.050^{* * *, \# \#}$ & $3.416^{* * *, \# \#}$ & & $1.352^{* * *, \# \#}$ \\
\hline
\end{tabular}

Notes: All values are expressed as mean \pm SEM, $n=6$. All data are subjected to One Way ANOVA followed by Bonferroni's multiple comparisons test; here Group II is compared with Group I, and Groups III, IV, V and VI are compared with Group II. ${ }^{*} \mathrm{p}<0.05, * * \mathrm{p}<0.01$, ***p $<0.001$, NS: Not Significant. Multiple Comparison: Group IV, V and VI are compared with Group III. \# p < 0.05, \#\# p < 0.01, \#\#\# p 0.001, NS: Not Significant.

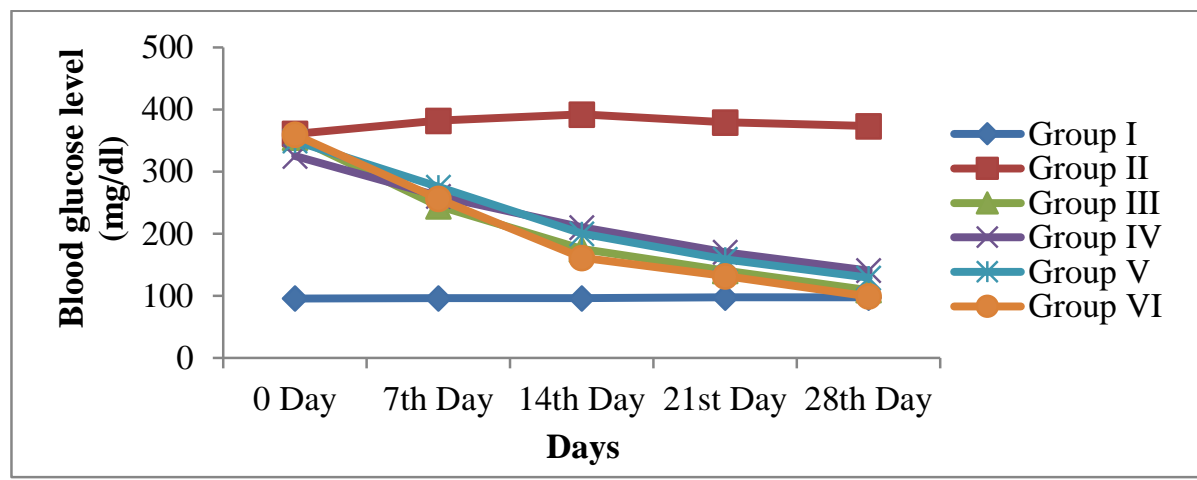

Figure 3: Effects of polyherbal extracts on blood glucose level in STZ-NIC induced diabetic mice; values are expressed as mean \pm SEM, $n=6$. Where, Group I: Normal control, Group II: Disease control, Group III: Standard control, Group IV: polyherbal extract treated $100 \mathrm{mg} / \mathrm{kg}$, Group V: polyherbal extract treated $200 \mathrm{mg} / \mathrm{kg}$, Group VI: polyherbal extract treated $400 \mathrm{mg} / \mathrm{kg}$.

\section{Effects of polyherbal extracts on lipid profile}

The levels of serum lipids are usually elevated in DM and such an elevation represents a risk factor for coronary heart disease. This abnormally high level of serum lipids is mainly due to the uninhibited actions of lipolytic hormones on the fat deposits due to the action of insulin. The regulation of lipid profiles in different groups of mice is exhibited in Table 5. A significant increase in TGL, total cholesterol and LDL, and a decrease in HDL was observed in Group II Disease control mice 
Jagtap et al. - In Vivo Antidiabetic Activities of Polyherbal Extracts against Streptozotocin ...

compared with Group I Normal control mice (Table 5). Groups IV, V and VI polyherbal extract-treated and Group III standard drugtreated mice showed significantly decreased TGL, total cholesterol, LDL, and increased HDL compared to Group II Disease control mice. The results of the study indicate the anti- hyperlipidaemic activity of the polyherbal extracts. The Group VI polyherbal extracttreated at dose of $400 \mathrm{mg} / \mathrm{kg}$ produced extreme anti-hyperlipidemic activity compared with Groups IV and V polyherbal extract-treated at doses of $100 \mathrm{mg} / \mathrm{kg}$ and $200 \mathrm{mg} / \mathrm{kg}$ (Figure 4).

Table 5: Effects of polyherbal extracts on lipid profile in STZ-NIC induced diabetic mice

\begin{tabular}{|c|c|c|c|c|c|c|c|}
\hline \multirow{3}{*}{$\begin{array}{l}\text { Sr. } \\
\text { No. }\end{array}$} & \multirow{3}{*}{$\begin{array}{l}\text { Treatment } \\
\text { Groups } \\
\text { Normal Control }\end{array}$} & \multicolumn{6}{|c|}{ Lipid profile mg/dl } \\
\hline & & Cholesterol & Triglyceride & & LDL & & HDL \\
\hline & & $\begin{array}{l}73.50 \\
2.078\end{array}$ & $\begin{array}{l}85.50 \\
0.3416\end{array}$ & \pm & $51.83 \pm 0.3074$ & & $69.07 \pm 0.2108$ \\
\hline II & $\begin{array}{l}\text { Disease } \\
\text { (Diabetic) } \\
\text { control }\end{array}$ & $\begin{array}{l}126.2 \\
1.078^{* * *}\end{array}$ & $\begin{array}{l}200.00 \\
0.3651^{* * * *}\end{array}$ & \pm & $\begin{array}{l}194.8 \\
0.5426^{* * * *}\end{array}$ & \pm & $24.0 \pm 0.3651^{* * *}$ \\
\hline III & $\begin{array}{l}\text { Standard } \\
\text { Control }\end{array}$ & $\begin{array}{l}82.33 \\
0.8433^{\text {*** }}\end{array}$ & $\begin{array}{l}86.17 \pm 1.62 \\
* * * \\
\end{array}$ & & $\begin{array}{l}51.27 \\
0.3073^{* * * *}\end{array}$ & \pm & $71.33 \pm 0.3333^{* * *}$ \\
\hline IV & $\begin{array}{l}\text { Polyherbal } \\
\text { extract treated I } \\
100 \mathrm{mg} / \mathrm{kg}\end{array}$ & $\begin{array}{l}95.50 \quad \pm \\
1.839^{* * *, \# \# \#}\end{array}$ & $\begin{array}{l}95.83 \\
0.3073^{* * *, \# \# \#}\end{array}$ & \pm & $\begin{array}{l}58.33 \\
0.4126^{* * *, \# \# \#}\end{array}$ & \pm & $\begin{array}{l}74.50 \\
0.6191^{* * *}, \# \# \#\end{array}$ \\
\hline $\mathbf{V}$ & $\begin{array}{l}\text { Polyherbal } \\
\text { extract treated II } \\
200 \mathrm{mg} / \mathrm{kg}\end{array}$ & $\begin{array}{l}90.33 \pm \\
0.5578^{* * *}, \# \# \#\end{array}$ & 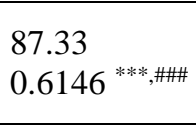 & \pm & $\begin{array}{l}54.83 \\
0.3073^{* * *, \# \# \#}\end{array}$ & \pm & $\underset{* * *, \# \# \#}{68.17} \pm 0.1666$ \\
\hline VI & $\begin{array}{l}\text { Polyherbal } \\
\text { extract treated } \\
\text { III } 400 \mathrm{mg} / \mathrm{kg}\end{array}$ & $\begin{array}{l}71.17 \pm \\
0.4773^{\text {*** }} \text {,\#\# }\end{array}$ & $\begin{array}{l}83.33 \\
0.4216^{* * *, n s}\end{array}$ & \pm & $\begin{array}{l}52.00 \\
0.3651^{* * *, \# \# \#}\end{array}$ & \pm & $\begin{array}{l}59.00 \\
0.3651^{* * * *, \# \# \#}\end{array}$ \\
\hline
\end{tabular}

Notes: All values are expressed as mean $\pm \mathrm{SEM}, \mathrm{n}=6$. All data are subjected to One Way ANOVA followed by Bonferroni's multiple comparisons test; here Group II is compared with Group I and Groups III, IV, V and VI are compared with Group II. $* p<0.05$, **p $<0.01$, ***p $<0.001$, NS: Not Significant. Multiple Comparison: Groups IV, V and VI are compared with Group III. \# $p<0.05$, \#\# $\mathrm{p}<0.01$, \#\#\# $\mathrm{p}<0.001$, NS: Not Significant.

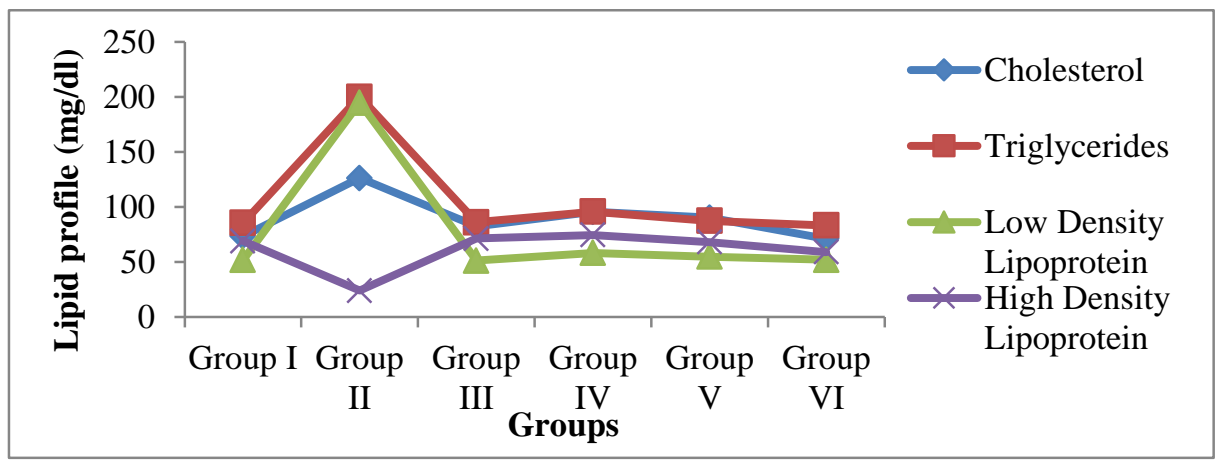

Figure 4: Effects of polyherbal extracts on lipid profile in STZ-NIC induced diabetic mice; values are expressed as mean \pm SEM, $n=6$. Where, Group I: Normal control, Group II: Disease control, Group III: Standard control, Group IV: polyherbal extract treated $100 \mathrm{mg} / \mathrm{kg}$, Group V: polyherbal extract treated $200 \mathrm{mg} / \mathrm{kg}$, Group VI: polyherbal extract treated $400 \mathrm{mg} / \mathrm{kg}$. 


\section{Histopathologic analysis of pancreas}

At the end of the study, the histopathology of the pancreas was done; results are shown in Figure 5. In Group II (Disease control), the histopathologic analysis of the pancreas revealed severe congestion, a huge decrease in the number of islets of Langerhans and $\beta$ cells, and fibrosis and inflammatory cell infiltration into the islets of Langerhans. Group III (Standard control) treated with drug metformin showed moderate congestion with a comparatively lower decrease in the number of islets of Langerhans and $\beta$ cells and lymphocytic infiltration of mild nature. Groups IV and V, i.e., polyherbal extracts at doses of 100 and $200 \mathrm{mg} / \mathrm{kg}$, respectively also showed moderate congestion with a moderate decrease in the number of islets of Langerhans and $\beta$ cells and mild lymphocytic infiltration. While the Group VI polyherbal extract at the dose of $400 \mathrm{mg} / \mathrm{kg}$ showed mild congestion and mild decrease in the number of islets of Langerhans with normal $\beta$ cell population indicating a significant amount of recovery.

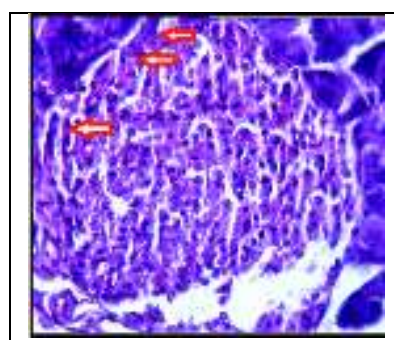

Group- I: NC

Pathological grade -

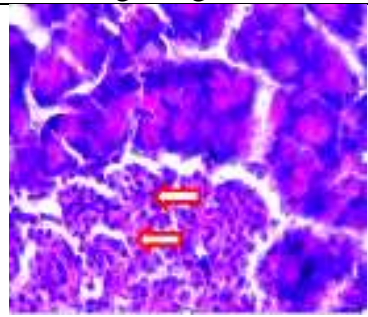

Group-IV:

Polyhetbs $100 \mathrm{mg} / \mathrm{kg}$

Pathological grade ++

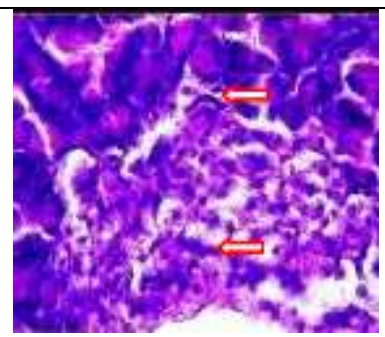

Group- II: DC

Pathological grade +++

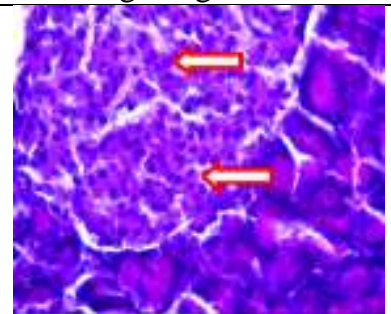

Group- V:

Polyherbs $200 \mathrm{mg} / \mathrm{kg}$

Pathological grade ++

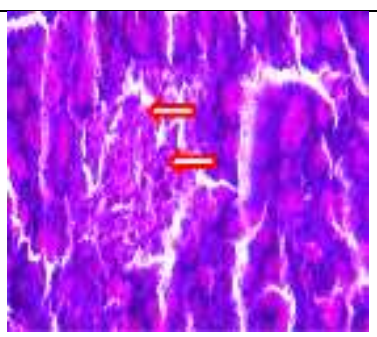

Group III : Std Control

Pathological grade ++

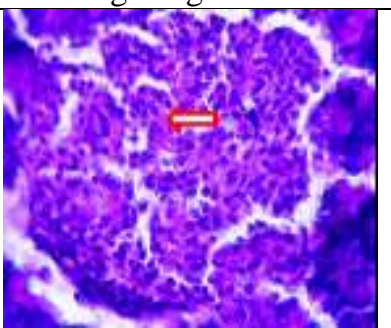

Group VI:

Polyherbs $400 \mathrm{mg} / \mathrm{kg}$

Pathological grade +

Figure 5: Pathological grades; Grade: -- no injury; Grade: +++ severe injury; Grade: ++ moderate injury; Grade: + mild injury.

Figure 5: Group I Normal control show “_” pathological grade which indicates no injury in tissue. The histopathologic analysis of pancreas revealed severe congestion, huge decrease in the number of islets of Langerhans and $\beta$ cells, and fibrosis and inflammatory cell infiltration into the islets of Langerhans in Group II Disease control which shows +++ pathological grade indicating severe injury. Group III Standard drug metformin treatment shows ++ pathological grade, i.e., moderate congestion with moderate decrease in the number of islets of Langerhans and $\beta$ cells, and mild lymphocytic infiltration. Groups IV and V, i.e. polyherbal extracts at doses of 100 and $200 \mathrm{mg} / \mathrm{kg}$, respectively also shows ++ pathological grade indicating moderate congestion with moderate decrease in the number of islets of Langerhans and $\beta$ cells and mild lymphocytic infiltration. While the group VI of polyherbal extract at $400 \mathrm{mg} / \mathrm{kg}$ showing + pathological grade indicates mild congestion and mild decrease in the number of islets of Langerhans with normal $\beta$ cell population, thereby indicating significant amount of recovery. 


\section{Discussion}

Various synthetic drugs are used for the treatment of hyperglycaemia, like insulin and oral hypoglycaemic agents. These synthetic drugs are associated with side effects which lead to limitations in their use and create issues in the management of diabetes. So, there is a need to develop safe and economic alternative treatments for diabetes mellitus. As such, there is considerable interest in the field of medicinal plants due to their natural origins and fewer side effects. In recent times, herbal formulations have gained greater importance mainly due to their efficacy and easy availability, as well as fewer side effects when compared to synthetic drugs. These advantages have led the people to move toward herbal preparations for disease treatment and prevention, as they are claimed to display synergistic, potentiate, and agonistic/antagonistic actions and the mixtures of species in them show better therapeutic effects than individual species on their own (Petchi et al. 2014, Mohapatra et al. 2016). Srivastava et al. (2012) noted that the concept of polyherbalism has been highlighted in Sharangdhar Samhita, Ayurvedic literature dating back to $1300 \mathrm{AD}$. Also, they highlighted any single herb concentration of polyherbal formulation is reduced which is also responsible for reducing the adverse effects. In the present study, polyherbal formulations containing extracts of leaves of Gymnema sylvestre, whole plant of Boerhavia diffusa, stem and leaves of Tinospora cordifolia, and whole plant Argyreia nervosa were selected for the antidiabetic study. The individual plants have already been determined to have antidiabetic activity. The polyherbal formulations were formulated using the ethanolic extracts of the leaves of Gymnema sylvestre, the whole plant of Boerhavia diffusa, stem and leaves of Tinospora cordifolia, and whole plant Argyreia nervosa. The antidiabetic activity of the individual plants has been proven. The leaves of the Gymnema sylvestre showed significant antidiabetic activity against STZ-induced diabetes at a dose of $400 \mathrm{mg} / \mathrm{kg}$
(Aralelimath and Bhise 2012), Boerhavia diffusa shows potent antidiabetic activity at dose of $200 \mathrm{mg} / \mathrm{kg}$ (Malhotra et al. 2014), Tinospora cordifolia shows potent antidiabetic activity at a dose of $400 \mathrm{mg} / \mathrm{kg}$ (Puranik et al. 2010), Argyreia nervosa shows potent antidiabetic activity at dose of $500 \mathrm{mg} / \mathrm{kg}$ (Kumar et al. 2010). The administration of polyherbal mixture exhibited significant antidiabetic effects and shows synergistic and potential actions against diabetes. The concentrations of the extracts were calculated from the references mentioned in the present study and worked for polyherbal extracts. The findings of the present study indicate the significant effects of the polyherbal extracts on streptozotocin-nicotinamide induced type 2 diabetic animals (mice).

Streptomyces achromogenes is a source of STZ, which is an antibiotic. Structurally, is a glucosamine derivative of nitrosourea. The nitrosourea moiety of this derivative is responsible for beta cell toxicity, while deoxyglucose moiety helps transport across the cell membrane. STZ causes alkylation or breakage of DNA strands and a consequent increase in the activity of poly-ADP-ribose synthetase, an enzyme depleting NAD in beta cells finally leading to energy deprivation and death of beta cells (Srinivasan and Ramarao 2007).

Recently, Undale et al. (2014) stated that a new animal model of type 2 diabetes has been produced by the combination of STZ and NIC administration in adult rats. The rats administered NIC (230 mg/kg, ip) $15 \mathrm{~min}$ before STZ $(65 \mathrm{mg} / \mathrm{kg}$, iv) have shown to develop moderate and stable non-fasting hyperglycaemia without any significant changes in plasma insulin levels. As NIC is an antioxidant, it exerts a protective effect on the cytotoxic action of STZ by scavenging free radicals and causes only minor damage to pancreatic beta-cell mass-producing type 2 diabetes. Therefore, this model has been found to be an advantageous tool for the investigation of insulinotropic agents in the treatment of type 2 diabetes (Undale et al. 2014). 
The principle objective in the treatment of diabetes mellitus is to decrease the elevated blood glucose to normal physiological level to prevent further micro and macrovascular complications. In this study, metformin was used as a standard drug. Metformin is accepted as a first-line antidiabetic agent for the management of type 2 diabetes. It is suited for the treatment irrespective of body weight, age, severity of hyperglycaemia and provides an agreeable pharmacological base for therapy in conjunction with other antidiabetic agents (Scarpello and Howlett 2008). Metformin has lower mortality and cardiovascular risks as compared to other insulin secreting agents such as glimepiride, glibenclamide, glipizide and tolbutamide in patients with type 2 diabetes mellitus. Metformin also does not produce hyperglycaemia since it does not stimulate insulin secretion when administered alone in patients with type 2 diabetes mellitus (Wright et al. 2006). As shown in Table 1, reduction in body weight observed in diabetic mice might be the result of degradation of structural proteins and fats due to deficiency of carbohydrates for the energy metabolism and significant increase in body weight of diabetic mice treated with polyherbal extracts showed the blood glucose stabilization effect which in turn prevents the loss of body weight.

Glucose tolerance test is a standard procedure that determines how rapidly exogenous glucose can be cleared from the blood. Insulin is important for regulating the uptake of glucose from the blood by cells. Soni et al. (2018), explained impairment of glucose tolerance, which means takes a longer time to clear a given amount of glucose divulges problems with the maintenance of glucose homeostasis (insulin resistance, carbohydrate metabolism, diabetes, etc).

As seen in Table 2, in Group VI mice treated with a polyherbal extract at the dose of $400 \mathrm{mg} / \mathrm{kg}$, a significant $(\mathrm{p}<0.001)$ decrease in blood glucose level at $90 \mathrm{~min}$ and $120 \mathrm{~min}$ was observed as compared to Group-III treated with standard drug metformin. The results indicated that the polyherbal extract at the dose of $400 \mathrm{mg} / \mathrm{kg}$ increases the clearance of the glucose from the blood which might be due to enhanced uptake of glucose from the cells which is regulated by insulin.

The diabetes was induced in mice after administration of streptozotocin-nicotinamide. As shown in Table 3, a consistent decrease in the blood glucose level was observed in the groups treated with metformin (Group III) and polyherbal extract-treated Groups IV, V and VI. In Group VI, polyherbal extracts at the dose of $400 \mathrm{mg} / \mathrm{kg}$, a significant $(\mathrm{p}<0.001$ ) decrease in blood glucose level at 28 days was observed as compared to Group III treated with metformin (250 mg/kg, p.o.). While in Groups $\mathrm{IV}$ and $\mathrm{V}$ no significant decrease in blood glucose level at 28 days was observed as compared to Group III. The results suggest the potential effects of polyherbal extract-treated at dose of $400 \mathrm{mg} / \mathrm{kg}$ at 14,21 and 28 days of treatments. The possible mechanism by which polyherbal extract brings about its hypoglycemic action in diabetic mice maybe by potentiating the insulin effect of plasma by increasing either the pancreatic secretion of insulin from the existing beta cells or by its release from the bound form.

Dyslipidaemia is a secondary complication accompanied by long term effects of diabetes and had been discussed many times during the past decades. During diabetes, the levels of TGL, cholesterol and LDL increase and the HDL levels decline significantly. In the diabetic model, abnormal concentrations of serum lipids might be due to a disturbance in hormone-sensitive enzyme lipase. The lipase enzyme concentration allows the mobilisation of free fatty acids from the peripheral fat repository because of insulin deficiency (Soni et al. 2018). The administration of polyherbal extract significantly restored cholesterol, TGL, LDL and HDL levels to their normal values in diabetic mice, which might be due to its lipidlowering activity. Therefore, this polyherbal extract also plays a significant role against diabetes-associated complications.

Histopathology of the pancreas of STZ-NIC diabetic animals showed a severe decrease in 
the number of islets of Langerhans and $\beta$ cells, with fibrosis and inflammatory cell infiltration into the islets of Langerhans. Polyherbal extract and metformin treatment to the animals reduced the severity of the histopathologic changes caused by STZ.

\section{Conclusion}

Chemically active principles present in the studied plants may be responsible for the observed antidiabetic effect of the polyherbal extracts. The hypoglycaemic effect produced by the polyherbal formulations may be due to the glycosides, flavonoids, tannins, and saponins present in the extracts. From the present study, it could be concluded that the administration of polyherbal formulations containing extract of Gymnema sylvestre, Boerhavia diffusa, Tinospora cordifolia and Argyreia nervosa exhibited significant antidiabetic effects by controlling the blood glucose levels. Additionally, the polyherbal formulations decreased total cholesterol, triglycerides and LDL, with an increase in HDL at the end of the treatments. The polyherbal extract-treated Group VI (400 $\mathrm{mg} / \mathrm{kg}$ ) exhibited maximum antidiabetic activity compared to the polyherbal extracttreated Group IV (100 mg/kg) and Group V (200 mg/kg). The significant hypoglycaemic activity of the polyherbal formulation might be due to the varied mechanism of action of each herbal drug present in the formulations. Hence, the developed polyherbal formulation might prove to be a potential safe alternative for the existing anti-diabetic synthetic drugs.

\section{Acknowledgement}

The authors are thankful to Pune District Education Association for providing animal house facilities during study. The author Dr. Patil is thankful to the DS Kothari Fellowship program, University Grants Commission and Savitribai Phule Pune University for the financial support during the post-doctoral research, this research idea emerged during the study.

\section{Ethics Approval and Ethical statement}

The experimental protocols were approved by the Institutional Animal Ethical Committee of PDEA's Seth Govind Raghunath Sable College of Pharmacy, Saswad (Ref. No. SGRS/IAEC/07/2019-20).

\section{References}

American Diabetes Association 2451 Crystal Drive, Suite 900, Arlington, VA 22202 1-800DIABETES https://www.diabetes.org/diabetes

Aralelimath VR and Bhise Sb 2012 Anti-diabetic effects of Gymnema Sylvester extract on streptozotocin induced diabetic rats and possible B-cell protective and regenerative evaluations. Digest J. Nanomater. Biostruct. 7: 135-142.

Birgani GA, Ahangarpour A, Khorsandi L and Moghaddam HF 2018 Anti-diabetic effect of betulinic acid on streptozotocin-nicotinamide induced diabetic male mouse model. Braz. J. Pharm. Sci. 54(2): 1-7

Chaudhuri A and Sharma S 2016 Evaluation of antidiabetic activity of polyherbal formulation in streptozotocin induced diabetic rats. Pharm. Biosci. J. 4: 01-06.

El-Shafey AAM, El-Ezabi MM, Selim MME, Ouda HHM and Ibrahim DM 2013 Effect of Gymnema sylvestre $\mathrm{R}$. Br. leaves extract on certain physiological parameters of diabetic rats. J King Saud Uni. Sci. 25: 135-141.

Galani VJ, Patel BG and Patel NB 2010 Argyreia speciosa (Linn. f.) sweet: a comprehensive review. Pharmacogn. Rev. 4(8): 172-178.

Gosh MN 1984 Toxicity studies, Fundamentals of Experimental Pharmacology, Scientific Book Agency, Calcutta, pp. 153-158.

Kanetkar P, Singhal R and Kamat M 2007 Gymnema sylvestre: a memoir. J. Clin. Biochem Nutr. 41(2): 77-81.

Kanetkar P, Singhal R, and Kamat M 2007 "Gymnema sylvestre: a memoir. J. Clin. Biochem. Nutr. 41(2): 77-81.

Kumar S and Alagawadi KR 2010 Hypoglycemic effect of Argyreia nervosa root extract in normal and streptozotocin-diabetic rats. Der Pharmacia Lettre 2(2): 333-337.

Malhotra D, Ishaq F and Khan A 2014 Antihyperglycemic activity of Boerhaavia diffusa in streptozotocin induced diabetic rats. Int. J. Chem. Anal. Sci. 5(1): 21-23.

Mandlik RV, Desai SK, Naik SR, Sharma G and Kohli RK 2008 Antidiabetic activity of a 
polyherbal formulation (DRF/AY/ 5001), Indian J. Exper. Biol. 46: 599-606.

Maurya AK, Tripathi S, Kahrana M, Ahmed Z and Sahu RK 2011 Evaluation of antidiabetic effects of Ficus racemosa extracts in diabetic induced rats, Pharmacologyonline 3: 907-914.

Mishra S, Aeri V, Gaur P and Jachak SM 2014 Phytochemical, therapeutic, and ethnopharmacological overview for a traditionally important herb: Boerhavia diffusa Linn. BioMed Res. Int. 2014: 808302, 19 pages.

Mohapatra L, Bhattamishra SK, Panigrahy R, Parida S and Pati P 2016 Antidiabetic effect of Sargassum wightii and Ulva fasciata in high fat diet and multi low dose streptozotocin induced type 2 diabetic mice. Pharm. Biosci. J. 4: 13- 23

Mouri MI and Badireddy M 2019 Hyperglycaemia, Stat Pearls, Treasure Island, FL, USA, pp1-5.

Nagja T, Kumar V and Sanjeev A 2017 Antidiabetic activity of a polyherbal formulation in streptozotocin induced type 2 diabetic rats. $J$. Nat. Remed. 16(4): 148-152.

Petchi RR, Vijaya C and Parasuraman S 2014 Antidiabetic activity of polyherbal formulation in streptozotocin-nicotinamide induced diabetic Wistar rats. J. Tradit. Complement. Med. 4:108 117.

Puranik N, Kammar K and Devi S 2010 Antidiabetic activity of Tinospora Cordifolia (willd.) in streptozotocin diabetic rats; does it act like sulfonylureas? Turk. J. Med. Sci. 40: 265-270.

Rakieten N, Rakieten ML and Nadkarni MV 1963 Studies on the diabetogenic action of streptozotocin, Cancer Chemother. Rep. 29: 9198.

Sancheti SS and Seo SY 2009 Chaenomeles sinensis: A potent $\alpha$-and- $\beta$ glucosidase inhibitor. Am. J. Pharmacol. Toxicol. 4: 8-11.

Scarpello JHB and Howlett HC 2008 Metformin therapy and clinical uses. Diab. Vasc. Dis. Res. 5: 157-167.

Shah S, Manigauha A and Dubey B 2019 Formulation and evaluation of antidiabetic and antihyperlipidemic activities of polyherbal formulation in streptozotocin induced diabetic rat. Pharm. Biosci. J. 7(1): 26-30.

Sharma P, Dwivedee BP, Bisht D, Dash AK and Kumar D 2019 The chemical constituents and diverse pharmacological importance of Tinospora cordifolia, Heliyon 5(9): e02437.

Sheikh Y, Manral MS, Kathait V, Prasar B, Kumar $\mathrm{R}$ and Sahu RK 2015 Computation of in vivo antidiabetic activity of Holarrhena antidysenterica seeds extracts in Streptozotocininduced diabetic rats. Iranian J. Pharmacol. Therapeut. 14(2): 22-27.

Simon K and Wittmann I 2019 Can blood glucose value really be referred to as a metabolic Parameter? Rev. Endocr. Metab. Disord. 20: 151-160.

Soni L, Dobhal M, Arya D, Bhagour K, Parasher P and Gupta R 2018 In vitro and in vivo antidiabetic activity of isolated fraction of Prosopis cineraria against streptozotocininduced experimental diabetes: a mechanistic study. Biomed. Pharmacother. 108: 1015-1021.

Srinivasan K and Ramarao P 2007 Animal models in type 2 diabetes research: an overview, Indian $J$. Med. Res. 125: 451-472.

Srivastava S, Lal VK and Pant KK 2012 Polyherbal formulations based on Indian medicinal plants as antidiabetic phytotherapeutics, Phytopharmacology 2: 1-15.

Turner RA 1965 Screening Method in Pharmacology, Academic Press, New York, pp. 22-41.

Undale VR, Bhosale AV and Upasani CD 2014 Study of pharmacodynamic interaction between a polyherbal formulation BSL-150 and Metformin, Pharm. Crops 5: 67-76.

Wild S, Roglic G, Green A, Sicree R and King H 2004 Global prevalence of diabetes-estimates for the year 2000 and projections for 2030. Diabetes Care 27(3): 1047-1053.

Wright AD, Cull CA, Macleod KM and Holman RR 2006 Hyperglycaemia in type 2 diabetic patients randomized to and maintained on monotherapy with diet, sulfonylurea, Metformin, or insulin for 6 years from diagnosis: UKPDS73, J. Diabet. Compl. 20: 395-401.

Yari Z, Behrouz V, Zand H and Pourvali K 2020 New insight into diabetes management from Glycemic index to dietary Insulin index, Curr. Diabetes Rev. 16(4): 293-300.

Zhang P, McGrath B, Li S, Frank A, Zambito F, Reinert J, Gannon M, Ma K, McNaughton K and Cavener DR 2002 The PERK eukaryotic initiation factor 2 alpha kinase is required for the development of the skeletal system, postnatal growth and the function and viability of the pancreas. Mol. Cell. Biol. 22: 3864-3874. 